\title{
Empowering practical wisdom from religious traditions: a ricoeurian approach
}

\author{
André Habisch ${ }^{*}$ (D) and Claudius Bachmann
}

\begin{abstract}
Multiple strains of research are currently claiming to bring back normative perspectives into business analysis. In line with a series of publications from different disciplines we refer to the traditional concept of Practical Wisdom for that purpose but link it substantially with narrations from religious and spiritual traditions. Aware of potential resistance against such a project we discuss some basic objections, which might be provoked inside of the business education community. Critics question religious and spiritual traditions as such but also their relevance for modern business practice. Referring to to Paul Ricoeur's concept of metaphorical language we critically sketch a practical wisdom-based approach that employs religious and spiritual traditions as point of reference for responsible management practices but avoids the trap of fundamentalism or normative reductionism. Finally, we will conclude by suggesting the scope of possible applications and the direction of further research.
\end{abstract}

Keywords: Paul Ricoeur, Practical wisdom, Prudence, Religion, Responsible management, Spiritual traditions, Wisdom

\section{Introduction}

According to a widespread consensus in management literature, the recent economic crisis and the environmental scandals of the last decades are nourishing the suspicion that today's mainstream management theories are counteracting rather than promoting human flourishing and sustainable development within business and society (Adler 2014; Ferraro et al. 2005; Ghoshal 2005). While shifting the guiding questions from the rather moral concerns about 'better' versus 'worse' towards the mere technical calculus of 'more' over 'less' (Dierksmeier 2011), it is said that conventional management theories are dramatically sidelining a normative orientation and a professional ethos (Crossan et al. 2013; Khurana 2007; Pfeffer and Fong 2004). Although they emphasize scientific rationalism and elaborating sophisticated mathematical models, they sometimes have no higher order ideals but a simple pay-off matrix that is assessed in quantitative and financial terms (Giacalone 2004).

Facing this lack of normative orientation within economic theory and practice, over the years several concepts like Business Ethics, Corporate Sustainability,

\footnotetext{
* Correspondence: andre.habisch@ku.de

Faculty of Economics and Business Administration, Catholic University of Eichstätt-Ingolstadt, Auf der Schanz 49, D-85049 Ingolstadt, Germany
}

Stakeholder Theory, Good Corporate Governance, Corporate Citizenship and, most commonly, Corporate Social Responsibility etc. have emerged. Subsequently, they produced some impact on business practice (cf., Margolis and Walsh 2003; Schneider and Schmidpeter 2012) and recently also conquered their territory in management studies (cf., Garriga and Melé 2004) and management education (cf., Matten and Moon 2004; Orlitzky and Moon 2008). In a general sense, two lines can be distinguished within the extensive field of research on Corporate Social Responsibility in management. On the one side, the instrumental view on Corporate Social Responsibility (CSR) mainly examines the potential for organizations of how to benefit financially when addressing environmental or societal concerns (cf., Hahn et al. 2010; Margolis and Walsh 2003). Some scholars are following a win-win approach which seeks to align environmental protection and social engagement with profitability (e.g., Beckmann et al. 2014; Plaza-Úbeda et al. 2009). Since the win-win lens does not always apply, others have developed a trade-off approach which seeks to achieve a compromise of prioritizing economic concerns without entirely scarifying societal and ecological concerns (cf., Slawinski and Bansal 2015). In sum, these approaches address sustainability issues 
with an economic rationale and advocate the point that companies can create a shared value between the economic performance of the firm and the benefits for society (Porter and Kramer 2006). This business case perspective on concepts like CSR and CS is more easily adaptable to the economic way of thinking and has undoubtedly made an important contribution to legitimize and mainstream CSR in economics. Nevertheless, all-too-often the instrumental view has been absorbed fully and finally into the conventional management paradigms giving up the transformative and innovative potential of normative orientation. As far as we know, it was only Baron Munchausen who was capable to tear himself out of the morass at his own hair tuft. Therefore, it appears highly questionable that the instrumental perspective as such may sufficiently contribute to the necessary normative realignment of mainstream management theory and practice.

On the other side, a conventional normative view on CSR and CS is usually based on political (e.g. Scherer and Palazzo 2007), philosophical (e.g. Fontrodona and Sison 2006) or ethical (e.g. Melé 2012) theories. While quite heterogeneous in terms of approach and theoretical background, this field of research usually argues that corporations ought to accept their social and environmental responsibilities as part of their obligations and duties. These approaches are embracing the full range of deontological, teleological, contractual, and virtueethical rationales but they have in common to construct corporate responsibility as part of a theoretical argumentation. As such, they represent an indispensable counterbalance to the instrumentalist tendencies in business. They still hold dear the importance of intrinsic values which do not require further external or instrumental benefits within a profit and outcome focused environment. However, in many cases these attempts still remain rather intellectual endeavors which provide an elaborated and well-reasoned ground but miss the question of implementation and practical integration. In order to develop any profound impact on the behavior of managerial decision makers for the promotion of sustainable management as a new business paradigm, in most parts of the world a normative concept should develop roots in the cultural and spiritual traditions.

In order to bring normative aspects back on the stage of today's global business world and to bridge the gap between rather instrumental approaches on the one side and rather abstract approaches on the other, the recent discussion suggests to again draw on Religious and Spiritual Wisdom traditions (King 2008). To do so, however, a thorough methodological reflection is required which would reflect the genuine conceptual challenges, which arise from such an endeavor. Therefore, in what follows we discuss some basic objections against religious traditions in management. Subsequently we sketch a conceptual approach, which refers to the Ancient concept of Practical Wisdom, which is in line with the Hermeneutical approach of the French philosopher Paul Ricoeur. Where should sources of normative traditions and orientations be originated which are able to serve as a means for a basic re-orientation?

\section{Spiritual traditions as a source of practical wisdom for responsible management}

In view of this question, we will take up an ancient concept, which has lately been enjoying a remarkable renaissance in management theory and practice: practical wisdom. Reviving the Aristotelian notion of phrónêsis, management scholars are recently striving to establish a new managerial leitmotif that is both reasonable in nature and practical in scope. Inspired by recent research mainly in the fields of pedagogics, philosophy, theology, and psychology this fast-unfolding practical wisdomoriented discourse in management literature has been focused mainly on overcoming the gap between purely theoretical knowledge and practice-orientated skillfulness by simultaneously integrating moral and social aspects (see (Bachmann et al. 2014) for a more extended overview). A wide variety of approaches, adaptions, interpretations, and terminologies, however, characterizes this field of research. Some, for instance, pursue a neo Aristotelian-Thomistic approach and unfold practical wisdom as necessary and partially constitutive for human flourishing. In that perspective, the virtue of practical wisdom requires the openness to receive each particular situation as it is, the theoretical knowledge and the experience to choose and apply the fitting means, and the excellence of character to define the right ends (cf., Arjoon 2008; Beabout 2012; Melé 2010). Others operationalize practical wisdom through an empirical lens striving to identify scientific criteria for control, replication, and prediction regarding the nature and development of wisdom (cf., Baltes and Staudinger 2000; Birren and Svensson 2005; Trowbridge 2011).

Although quite heterogeneous in terms of approach and methodology, the aforementioned adaptions and other perceptions of practical wisdom in the literature commonly share the underlying assumption that practical wisdom transcends indifferent cleverness, tactical cunningness, or immoral underhandedness. Instead, it tackles the question of what ultimately orients someone's actions and decisions considering not just how to attain any end, but what to choose as an end worthy to pursue. As one of the key components of practically wise management, the basal need of the normative perspective could be re-emphasized in this way.

However, in contrast to the relatively homogenous views of the world at the times of Aristotle, when a 
determined, unique, and ultimate end was assumed for all human beings and so inferred what sorts of goals were to be regarded as 'wise' and worthwhile, nowadays we are faced with the highly diverse, frequently even controversial cultures, religions, beliefs, or attitudes of modern and globalized societies (Dierksmeier 2011). Therefore, a contemporary adaption of the idea of practical wisdom has to take into consideration the multilayered diversity of modern societies regarding, for instance, spiritual traditions, cultural values, and perceptions of the ultimate ends. While the philosophical rediscovery of the Aristotelian phrónêsis as well as the psychological adaption of practical wisdom may provide the formal framework, from our perspective it is the role of the spiritual traditions of humankind to contribute to the material side.

Interestingly, for many generations in human history it has been spiritual and religious education in which corresponding normative aspects of a responsible and value based leadership practice have been ingrained ${ }^{1}$. Albeit in very different cultural contexts and local modifications, religious traditions have played an important role in handing over personal values to a new generation of political and economic leaders. To better understand the close connection between leadership values and religion, it has to be recalled, that in the context of pre-modern living conditions, there has been only a very loose control of leadership practice by legal rules and institutions or sophisticated political or economic governance systems. On the contrary, the individual morality of leaders played an important role also for the stability of a social order, i.e. for establishing trust and mutual cooperation. In this constellation, religious values - albeit already in their plurality of different confessional and religious beliefs and traditions - played a crucial role as a 'cultural capital' to establish stabile mutual expectations. Even if with the School of Salamanca and later with Enlightenment in the Western world, humanistic moral traditions gradually emerged as a 'secular' alternative to a genuine religious education, the role of religious traditions for the character formation of leaders is still unchallenged among the majority of leaders globally.

In this sense, recent developments in management science focus in a very precise way on those aspects of personal meaning, purpose and values-based practice, for which spiritualties even in the complex world of the 21st century can play an important role (cf. Dyck 2014; King 2008; Kriger and Seng 2005; Tracey et al. 2014). In particular, in view of the obvious limitations of bonusschemes and corresponding means of extrinsic motivation in the financial sector, the corporate and environmental scandals of recent years and the disastrous breakdown in trust undermining the corporations' traditional "license to operate", an increasing number of scholars are advocating the argument that religious ideas might enhance or renew mainstream management theory and practice and, thus, positively transform society at large (Dyck et al. 2009; Melé 2012; Rynes et al. 2012). It was Helen Alford (2010) to explicitly state that "we cannot continue ignoring resources from the world's religions if they can help us come up with the best answers of which we are capable" (p. 704).

In this vein, some scholars presently seek to rediscover the religious resources of practical wisdom (e.g., Alford 2010; Habisch and Bachmann 2016; Kriger 2013; Lenssen et al. 2010; Naughton et al. 2010; Whittington et al. 2005). The fund of beliefs, examples, and role models that are transmitted from generation to generation through the proverbs, analetcs, suras, tales, and parables, reinforced by their oral traditions, and adapted time and again into the particular, specific realities provide a source of practical wisdom for purpose-driven business. In that context, spiritual texts as sources of practical wisdom may be approached and understood separately from the hierarchical context of organized religious traditions.

\section{The dark side of religious spirituality: objections against a spiritual traditions-based approach to practical wisdom}

Despite of the described attractiveness of a concept of practical wisdom rooted in existing spiritual traditions, also three severe objections have been raised - questioning corresponding efforts in general. Those refer to the dark sides of religious traditions.

Objection 1: Spiritual traditions cannot serve as a suitable basis for practical wisdom in management, because they have regularly nurtured intolerance, controversy and violation of Human rights during the course of $\mathrm{Hu}$ man history.

During the centuries of Human history negative aspects of religious traditions have certainly become obvious: Religious beliefs have served (and still serve today) as an excuse for intolerance and prejudices, for severe violations of Human rights (e.g. by refusing to extend them to the non-believer), for prosecution of minorities etc. Moreover, religious and confessional differences have been and still are sources of especially destructive wars between nations and groups. Spectacular examples in history include the genocide against indigenous cultures in Middle and Southern America, the Thirty Years' War in Central Europe, the century-long bloody conflicts between Christians and Muslims on the Iberian Peninsula as well as South-Eastern Europe, to name but a few. More recently, conflicts between Catholic and Protestant Christians in Ireland, between Muslims and Hindus in India and Pakistan, between Christians and Muslim in Sub-Saharian Africa, between Sunni and 
Schia Muslims in Iraque etc. have to be mentioned. Moreover, terrorists invoking religious beliefs are clearly on the rise in recent years - for example the Lord's Resistance Army in Central Africa, the Al-Shabab in Somalia or Boto Haram in Nigeria. Besides these prominent socio-political examples, there is research in organizational and management literature, which examines the dangers of religious instrumentalism (Lips-Wiersma et al. 2009), for instance concerning worker exploitation and increased groupthink and discrimination (Polley et al. 2005) or reduced effectiveness of organizational decision making and increased risk of financial fraud (Koerber and Neck 2006). Following Lips-Wiersma et al., abusive practices emerge around the two dimensions of 'instrumentality' and 'control' and include seduction, evangelization, manipulation and subjugation. In this sense, any attempt to employ spiritual and religious values for the orientation of business practice have to clearly dissociate itself from any form of fundamentalist mishandling or dogmatic instrumentalization.

Objection 2: Spiritual traditions are contradicting with the secured realizations of a contemporary scientific analysis.

Another development in the Western society of the $19^{\text {th }}$ century discredited the influence and the intellectual credibility of religious and spiritual traditions: the philosophical and scientific critique of religious explanations as mere extrapolations of naïve anthropocentrism. This process already started with Galilei and Copernicus, who in astronomy denounced the Ptolemaic worldview; Charles Darwin did so in biology developing a mere secular evolutionary theory of the Human species against a literal concept of Divine Creation; finally, Sigmund Freud even attacked traditional religious teachings in their 'core discipline' of virtue ethics and personal morality, i.e. with his psychoanalytic critique of a naïve concept of the Human mind as a self-aware and therefore self-possessing control unit. Since then, at least in Western societies, prevailing religious concepts were perceived as being gradually on the retreat. This tendency was described by the sociological theory of secularization, which affirms that with the spread of modernity (including its elements of individualism, enlightened rationality, pluralism etc.), religiosity is losing ground. Consequently, scholars like Prothero (2008) note a growing 'religious illiteracy' in modern societies. Analogously, during the first half of the 20th century, the zeitgeist to detach modern sciences from any spiritual or religious moorings was taken over by the economic community as well (cf., King 2008, 217 f.; Tracey et al. 2014, 5-8). Consequently, the employment of methods beyond the scope of empirical observation and positivistic thinking was discredited and - due to its limited scientific validity - the non-empirical dimension of spirituality and values was systematically excluded from the analysis of business decisions (Dierksmeier 2011).

Therefore, any attempt to bring a spirituality-based perspective back into a normative discourse in business has to prove its scientific reliability and transdisciplinary accessibility in modern commercial contexts.

Objection 3: Spiritual traditions are rooted in premodern social order and are therefore of little value in a contemporary complex world.

From a hermeneutical perspective, the fundamental gap between the context in which the great faith traditions of humankind emerged, and today's totally different modern business experience appears to be prohibitive. Nearly all the major spiritual traditions emerged hundreds and thousands of years ago. The Hindu scriptures from the Vedic tradition have gradually emerged literally thousands of years ago, the oldes of them - the Samhitas - emerged as early as 1700-1100 BCE. The oldest monotheist tradition, the Zoroastrian religion (which is today still represented in the Parsi culture and spirituality in India) dates back to no later than 1200 years BCE. In what the German philosopher Karl Jaspers called the Axial times (i. e. the $6^{\text {th }}$ century BCE) the Jewish tradition in the Middle East and Buddhism in India emerged more or less simultaneously. The Christian and the Islam tradition (emerging during the $1^{\text {st }}$ and the $6^{\text {th }}$ century CE in the Middle East as well) as the most recent ones nevertheless still share important characteristics with the above mentioned spiritualties. From a socio-economic perspective, all of them are deeply rooted in their social context, which is the world of agrarian and static economies. This world was by far less complex and natural living conditions played a much more important role compared with the 'second nature' of the modern industrial civilization or even the 'third nature' of today's digital world. Recent studies convincingly elaborated the radical abyss between those traditional contexts and the modern business society: the emergence of industrial society triggered an explosion of the per capita income of a simultaneously quickly rising population (Clark 2007). Never before in Human history did so many people live together on our planet and found themselves endowed with so many goods and services available to them (even if those are still very unevenly distributed and there still remains the scandal of thousands starving to death in the context of an affluent Global society). Moreover, as Acemoglu and Robinson (2012) have shown, the structure of most developed countries today differs substantially from the exploitative context in which mankind used to live in pre-modern times. These basal social, political, cultural, economic etc. differences are making doubtful the relevance and adaptability of the century-old ideas.

In this sense, a central challenge of empowering practical wisdom from the spiritual traditions is to 
demonstrate the way of how to bridge the fundamental hiatus between the context, in which the spiritual traditions of humankind emerged, and today's totally different modern business experience.

\section{Practical wisdom from spiritual traditions: a ricoeurian approach}

One contemporary theorist, whose multifaceted oevre has carefully argued in the context of those three challenges, is the French hermeneutical philosopher Paul Ricoeur. Ricoeur was in no way concerned with practical wisdom or business values. Rather he more basically questioned the role of any religious 'text' in the totally different 'con-text' of the contemporary secular world, which is in large parts increasingly skeptical against religions (Ricoeur 1995, 2008).

\section{The world of the text - le monde du texte}

According to Ricoeur, texts are a form of language and therefore represent a basic communication between a sender (the author or scripter) and a receiver (the reader) (Ricoeur 1970, 1974, 1978, 1980). Even the oldest texts we know - which are temple lists from antique cities in Mesopotamia - can be characterized by a certain significance, i.e. by the aim of demonstration. To analyze its specific structure one has to reflect on the relationship between speech and text. As a form of communication, the text presupposes a speech. However, when a speech is written down and becomes a text, it basically changes its character. The speech is an act of communication between a speaker and her addressee; this communication is taking place in the context of a shared context of meaning. As such, the speech has a relationship to the reality, which can be characterized by a dialectic structure between sense (content) and significance (presumption of truthfulness) (see Ricoeur 1974: 28). With the transformation from speech to text, however, the communication becomes independent from the intention of the communicator. The significance of the communication (i.e. of the text) is no longer identical with the intended significance of the communicator (i.e. what author wanted to say). More precisely, in the oral communication the primary significance of the speech assumes to demonstrate a common reality to the addressees, which is embedded in a common universe of meaning. By transforming speech into a written text, however, this primary significance is being destroyed. The destruction becomes especially manifest in fictive literature, which explicitly intends to destroy any primary significance of the communication. Referring to this hermeneutical observation, Ricoeur talks about the world of the text (le monde du texte) that is independent from the author as well as from the reader.
Furthermore, according to Ricoeur, this process of interpreting the specific world of the text has a twofold meaning: It is not only the reader who understands the text but it is also the text itself that induces a process of self-reflection and influences the self-understanding of the reader. In this sense, by entering into a text, the reader modifies his/ her own perception of the world and potentially develops new ways of his/ her being-in-the-world. The text may become the medium, by which we understand our own being-in-the-world.

Summing up, according to Ricoeur, a written text cannot be perceived as an instrument of communication between the author and the reader. Rather the world of the text, which historically emerged with the speech becoming text, serves as prerequisite for the perpetually ongoing re-interpretation of the text as an autonomous subject. On the other side, by interpreting the text the reader himself may disclose his own contemporary world and re-interpret himself in the context of his contemporary world.

\section{Symbolic language and metaphorical texts}

This twofold meaning of the reading of a text is especially relevant for metaphorical texts employed in religious and spiritual traditions. In order to understand the character of religious and spiritual traditions, the reflection about the specific nature of metaphorical texts is of crucial importance. In the context of spiritual traditions - especially of those, which are grounded on textual traditions like Holy Scriptures - the metaphorical text is a symbol for the Divine or Inspired. According to the hermeneutic philosophy of Ricoeur these text-world based symbols are multidimensional by nature. They can never be expressed exhaustively by rational scientific language. Rather, compared with the descriptive code of reports or analyses, they always retain a substantial 'plus', which leaves open space for their renewed interpretation from the different perspective of a (future) reader. As Ricoeur entitles one of his essays: "Le symbole donne à penser" the symbol provides food for thought.

Thus, rather than an immediate communication act between the (historical) author (of the $2^{\text {nd }}, 3^{\text {rd }}$ or $7^{\text {th }}$ century) and the contemporary reader, spiritual texts (as symbolic text) are opening-up the space for on-going reinterpretation and appropriation. Therefore, during the course of Human history, spiritual texts and religious motives ('symbols') are no longer tied to their original communication context. They are no longer bound to the historical concept of Human history or contingent, era-specific concepts of the world, which prevailed during time and place of their origin. Rather the autonomy of their text-world enables and even calls for a culturally 'updated' interpretation and appropriation. 
Originating from a Christian concept, Ricoeur elaborates his hermeneutical concept by exemplarily referring to the narratives of Jesus in the Synoptic Gospels. The Jesus of the Synoptic Gospels makes extensive use of metaphoric language, here. Instead of formulating plain statements about God, the world, or the duties of the Faithful, the synoptic Jesus is rather telling parables, e.g. about God as the merciful father, the Kingdom of God as a winery, whose owner compensates his workers graciously, the prodigal son etc. Similar narrative traditions can be found in many other religious and spiritual traditions globally. According to Ricoeur, these spiritual narratives possess their own persuasive power, which differs substantially from mere descriptive statements. They disclose potentials for a renewed interpretation and appropriation of the situation of the reader - similar to a poem, a short story or even a witty joke. Like other forms of metaphorical language and narratives, the parables of the Christian Gospel express a meaning, which can always become a source of inspiration for a renewed and emancipative practice.

Metaphorical language, however, is not limited to the Christian tradition. Rather using another example from the Islam tradition, Qu'ran texts report, that the wife of the Prophet Muhammed was in her time a successful trader and entrepreneurial women and even older than the Prophet himself; she initially even employed him as a sales representative for a certain region. Again, this text is much more than information about the past. On the contrary, interpreted in the social context of Northern African societies at the beginning of the $21^{\text {st }}$ century, this symbolic text can become an important source of empowerment and emancipative inspiration for young female business students and entrepreneurs. The symbolic texts of Qu'ran and Haddith may empower young female entrepreneurs to liberate themselves from the prevailing formal or informal limitations based in certain tribal cultural traditions of their business context.

\section{Consequences for a managerial approach to Religious Traditions}

Based on these fundamental considerations inspired by Ricoeur's hermeneutical theory, we now attempt to face the threefold objection against a spiritual traditionsbased approach to practical wisdom in management. For that purpose, we start in a reverse order with the last objection:

3) It is true that all major spiritual traditions emerged during the times of pre-modern agrarian societies and therefore per se have no relationship whatsoever with modern business environment and business challenges. However, following the indication of Paul Ricoeur, spiritual texts have to be interpreted and applied according to their genuine metaphorical and 'symbolic' character.
Thus, they cannot be understood as a plain recommendation for any individual strategy, organizational policy or even governance structure in the highly complex business world of the 21st century. Interpreting traditional texts in this one-dimensional way would indeed result in a (fundamentalist) misunderstanding. Rather, instead of representing plain recipes for a better world, those metaphorical texts necessarily have to become applied by the individual reader. It is up to her or him to read, understand and interpret the text in the light of his experience and professional knowledge and to translate it into the design of the above mentioned business actions and/ or structures. Moreover, this process takes place in an institutional context - for example the context of the community of the faithful, the Umma of the Islamic communities etc. General rules for a proper interpretation of a text (i.e. integrating it in a hierarchical complex of multiple texts) may serve as a moderating element here, which is supposed to prevent extreme and potentially dangerous misinterpretations of a single text. However, this context does not imply that the essential receptive structure of reading and interpreting a metaphorical text is changed. Rather the above described reception process causes the central role of the individual person as a subject of interpretation and application. It is always the individual person herself, endowed with all her experience and professional knowledge, who interprets the text or at least who decides which interpretation offered by others she wants to follow. Due to this indispensable structure of the hermeneutical process, a spiritual text can well enfold its dynamics in the contemporary world, even if the historical authors themselves had necessarily lacked any experience and even the imagination of today's challenges.

2) As reflected above spiritual texts are conveying a multidimensional significance that goes beyond empirical definiteness and leaves room for an ever new adaptation from a contemporary reader's perspective and context. This openness for subjective adaptation, however, does not necessarily expulse them from the business school. On the contrary, a Practical Wisdom approach opposes the methodological reductionism of a management education practice, which is emulating natural sciences and their research methods as closely as possible and is therefore blinding itself for the complexity of Human business practice. Hence, the narrative character of spiritual communication does not impede but rather stimulate its application into contemporary business situations.

Nevertheless, even a careful spiritual analysis is required in order to avoid e.g. subjective arbitrariness, eclectic reductionism, or materialistic instrumentalism. Moreover, in order to convert spiritual wisdom into concrete business strategies, organizational features or 
governance policies, professional knowledge and experience is necessary. For example, if the spiritual inspiration to work for the integrity of the Divine creation results in the decision of a business woman to implement a sustainable production strategy, this decision does not substitute but rather calls for her rigorous professional implementation. For that purpose, she will well draw on her professional experience including the underlying scientific knowledge - thereby intuitively closing the hermeneutical gap between pre-modern spiritual text and contemporary concepts.

1) The final and probably most influential objection against spiritual traditions is their seemingly intolerant and illiberal character. As mentioned above, conflicting believe systems have regularly nurtured violations of $\mathrm{Hu}-$ man rights and explosions of aggressiveness against different groups people. However, if we profoundly analyze existing conflicts it becomes clear that religious reasons in many cases are not really at the heart of them. Rather, the hatred exemplarily resulting from economic discrimination and injustice, from political imperiousness and economic greed, or from distrust and suspicion is religiously legitimized even if it finds itself in contrast with the religious instructions and the concept of man, on which the most important religious concepts are based. Therefore, 'political entrepreneurs' or power holders invoke religion, because it is of high importance for many of their contemporaries and this dedication allows them to secure relatively 'cheap' support by legitimizing their political or economic strategies with religious arguments. Most of the same political entrepreneurs or power holders do not care at all about religious teachings as soon as their personal living standard and a dignified treatment of other people in their immediate surrounding is concerned. A logic of instrumentalization becomes obvious here, which regularly discredits religious beliefs in the public perception. It simply overshadows the obvious truth that for many believers living a religious life is an important motivation to civilize their life - including their economic practice - and humanize their attitudes against their fellow-beings.

\section{Conclusion}

In this paper we set out to delineate a practical wisdom approach towards responsible management, which especially reflects on the role of religious and spiritual traditions. As Paul Ricoeur's hermeneutical approach makes clear, symbolic texts - beyond their potential 'contextual' possession (and sometimes even instrumentalization) by religious hierarchies or even abuse by (totalitarian) pseudo-religious groups - may rather serve as a source of inspiration for individual actors and business leaders in their potentially very heterogeneous business context. They may serve as 'food for thought' ('Ils donnent à penser' according to P. Ricoeur) and in that sense they serve as ongoing 'cultural capital' of individuals as well as organizations.

Empowering Practical Wisdom: Spiritual traditions in business education: The title of our essay is therefore purposefully ambiguous and can be understood in a threefold way:

- If they are read and interpreted in the right way, symbolic texts can themselves become 'empowering' - in the sense that they encourage a renewed and emancipative practice of business Leadership, of crafting Corporate Governance structures etc.;

- however, in order to play that role, those texts also need empowerment themselves - in the sense that academic management teachers appropriate and integrate them in a reflected way into organized management education. Therefore, they have to overcome the widespread distrust against symbolic and metaphorical language in general and spiritual traditions in particular, which often results in a limitation of business education to allegedly 'valuefree' formal modeling and education.

- Finally, symbolic texts have to be empowered against their monopolization, possession, and instrumentalisation by religious systems. The later might in fact tend to prevent their appropriation by a self-confident community of non-theologian practitioners, who do no longer submit themselves to certain authoritative interpretations.

Which role may Practical Wisdom from the Religious traditions then play within today's global management context? We believe that metaphorical texts from spiritual traditions can empower renewed and emancipative business practices in very different areas of management. In particular, they can make a difference, here:

- On a personal level by strengthening sense-making and purpose in a truly 'professional' (Khurana) selfconscience of a business student and future manager.

- On an organizational level contributing to transform the organizational culture in a department or organizational unit and unleashing a spirit of innovation and courage or foster personal development.

- On a strategic or Corporate Governance level recreating a collective sense of the organization's role in society and promoting a spirit of Social innovation and service.

To conclude, Empowering Practical Wisdom from the Religious and Spiritual traditions remains an important 
project to overcome the reduction of Cultural Diversity. Rather it binds management education back to the regional cultural traditions therefor allowing to overcome a widespread alienation of young business students from their own cultural roots (see contributions in Habisch/ Schmidpeter 2016). Bringing large parts of the World's population back again into the renewal of the contemporary business education also requires the rediscovery of Spiritual traditions, which have been and still are a crucial element of personal and collective orientation in an ever more complicated World.

\section{Endnotes}

${ }^{1}$ See The Education of the Christian Prince from Desiderius Erasmus (written 1516, published 1532) as an example. This booklet written in the context of educating Habsburg Prince Charles (later Emperor Charles V.) but remained very influential during upcoming centuries as an expression of Christian Humanism.

\section{Acknowledgements}

This paper is inspired by and draws extensively from: Habisch, A., \& Bachmann, C. (2016). Empowering Practical Wisdom: Spiritual traditions and their role in the global business world of the 21 st century. In A. Habisch \& R. Schmidpeter (Eds.). Cultural Roots of Sustainable Management: Practical Wisdom and Corporate Social Responsibility (pp. 9-22). Switzerland: Springer International Publishing.

\section{Authors' contributions}

Both authors equally and substantially contributed to the conception drafting and revising of the work. Both authors read and approved the final manuscript.

\section{Competing interests}

The authors declare that they have no competing interests.

Received: 1 June 2016 Accepted: 15 July 2016

Published online: 25 August 2016

\section{References}

Acemoglu, D., \& Robinsons, J. (2012). Why Nations Fail. The Origins of Power, Prosperity and Poverty. New York: Crown Publisher.

Adler, P. S. (2014). Capitalism in Question. Journal of Management Inquiry, 23(2), 206-209.

Alford, H. (2010). The practical wisdom of personalism. Journal of Management Development, 29(7/8), 697-705.

Arjoon, S. (2008). Reconciling situational social psychology with virtue ethics. International Journal of Management Reviews, 10(3), 221-243.

Bachmann, C., Loza Adaui, C., \& Habisch, A. (2014). Why the Question of Practical Wisdom Should Be Asked in Business Schools: Towards a Holistic Approach to a Renewal of Management Education (Humanistic Management Network Research Paper Series). 2460665. Available from SSRN: http://ssrn.com/ abstract $=2460665$

Baltes, P. B., \& Staudinger, U. M. (2000). Wisdom: A Metaheuristic to Orchestrate Mind and Virtue Toward Excellence. American Psychologist, 55(1), 122-136.

Beabout, G. R. (2012). Management as a domain-relative practice that requires and develops practical wisdom. Business Ethics Quarterly, 22(2), 405-432.

Beckmann, M., Hielscher, S., \& Pies, I. (2014). Commitment Strategies for Sustainability: How Business Firms Can Transform Trade-Offs Into Win-Win Outcomes. Business Strategy and the Environment, 23(1), 18-37.

Birren, J. E., \& Svensson, C. M. (2005). Wisdom in History. In R. J. Sternberg \& J. Jordan (Eds.), A Handbook of Wisdom. Psychological Perspectives (pp. 3-31). New York: Cambridge University Press.

Clark, K. (2007). A Farewell to Alms: A Brief Economic History of the World. Oxfordshire: Princeton University Press.
Crossan, M., Mazutis, D., Seijts, G., \& Gandz, J. (2013). Developing Leadership Character in Business Programs. Academy of Management Learning \& Education, 12(2), 285-305.

Dierksmeier, C. (2011). The Freedom-Responsibility Nexus in Management Philosophy and Business Ethics. Journal of Business Ethics, 101 (2), 263-283.

Dyck, B. (2014). God on Management: The World's Largest Religions, the "Theological Turn", and Organization and Management Theory and Practice. In P. Tracey, N. Phillips, \& M. Lounsbury (Eds.), Religion and Organization Theory (pp. 23-62). Bingley: Emerald (= Research in the Sociology of Organizations 41).

Dyck, B., Starke, F. A., \& Dueck, C. (2009). Management, Prophets, and SelfFulfilling Prophecies. Journal of Management Inquiry, 18(3), 184-196.

Ferraro, F., Pfeffer, J., \& Sutton, R. I. (2005). Economics Language and Assumptions: How Theories can Become Self-Fulfilling. Academy of Management Review, 30(1), 8-24

Fontrodona, J., \& Sison, A. J. G. (2006). The nature of the firm, agency theory and shareholder theory: A critique from philosophical anthropology. Journal of Business Ethics, 66(1), 33-42.

Garriga, E., \& Melé, D. (2004). Corporate Social Responsibility Theories: Mapping the Territory. Journal of Business Ethics, 53(1/2), 51-71.

Ghoshal, S. (2005). Bad Management Theories Are Destroying Good Management Practices. Academy of Management Learning and Education, 4(1), 75-91.

Giacalone, R. A. (2004). A Transcendent Business Education for the 21st Century. Academy of Management Learning \& Education, 3(4), 415-420.

Habisch, A., \& Bachmann, C. (2016). Empowering Practical Wisdom: Spiritual traditions and their role in the global business world of the 21st century. In A. Habisch \& R. Schmidpeter (Eds.), Cultural Roots of Sustainable Management: Practical Wisdom and Corporate Social Responsibility (pp. 9-22). Switzerland: Springer International Publishing.

Hahn, T., Figge, F., Pinkse, J., \& Preuss, L. (2010). Trade-offs in corporate sustainability: you can't have your cake and eat it. Business Strategy and the Environment, 19(4), 217-229.

Khurana, R. (2007). From Higher Aims to Hired Hands. Princeton: Princeton University Press.

King, J. E., Jr. (2008). (Dis)Missing the obvious - Will mainstream management research ever take religion seriously? Journal of Management Inquiry, 17(3), 214-224.

Koerber, C. P. \& Neck, C. P. (2006). Religion in the Workplace: Implications for Financial Fraud and Organizational Decision Making. Journal of Management, Spirituality \& Religion, 3(4), 305-318.

Kriger, M. (2013). Wise Leadership in Organizations: Integrating Eastern and Western Paradigms. In J. Neal (Ed.), Handbook of Faith and Spirituality in the Workplace (pp. 255-269). New York: Springer.

Kriger, M., \& Seng, Y. (2005). Leadership with inner meaning: A contingency theory of leadership based on the worldviews of five religions. The Leadership Quarterly, 16(5), 771-806.

Lenssen, G., Malloch, T. R., Cornuel, E., Kakabadse, A. (2010). Practical wisdom in management from the religious and philosophical traditions. Journal of Management Development, 29(7/8)

Lips-Wiersma, M., Dean, K. L., \& Fornaciari, C. J. (2009). Theorizing the Dark Side of the Workplace Spirituality Movement. Journal of Management Inquiry, 18(4), 288-300.

Margolis, J. D.s \& Walsh, J. P. (2003). Misery Loves Companies: Rethinking Social Initiatives by Business. Administrative Science Quarterly, 48(2), 268-305.

Matten, D., \& Moon, J. (2004). Corporate social responsibility education in Europe. Journal of Business Ethics, 54(4), 323-337.

Melé, D. (2010). Practical wisdom in managerial decision making. Journal of Management Development, 29(7/8), 637-645.

Melé, D. (2012). Management Ethics: Placing Ethics at the Core of Good Management. New York: Palgrave Macmillan.

Naughton, M., Habisch, A., Lenssen, G. (2010). Practical wisdom in management from the Christian tradition. Journal of Management Development, 29(7/8)

Orlitzky, M., \& Moon, J. (2008). Second European Survey on Corporate Social Responsibility Research, Education and Other Initiatives in Business Schools and Universities (= Research Paper Series, International Centre for Corporate Social Responsibility, Nottingham University Business School 52-2008).

Pfeffer, J., \& Fong, C. T. (2004). The Business School, Business': Some Lessons from the US Experience. Journal of Management Studies, 41(8), 1501-1520.

Plaza-Úbeda, J. A., Burgos-Jiménez, J., Vazquez, D. A., \& Liston-Heyes, C. (2009). The 'win-win' paradigm and stakeholder integration. Business Strategy and the Environment, 18(8), 487-499. 
Polley, D., Vora, J., \& SubbaNarasimha, P. N. (2005). Paying the devil his due: Limits and liabilities of workplace spirituality. International Journal of Organizational Analysis, 13, 50-63.

Porter, M. E., \& Kramer, M. R. (2006). Strategy and society: The link between competitive advantage and corporate social responsibility. Harvard Business Review, 84(12), 78-92.

Prothero, S. (2008). Religious Literacy: What Every American Needs to Know - And Doesn't. New York: HarperOne.

Ricoeur, P. (1970). Freud and Philosophy: An Essay on Interpretation (trans. Denis Savage). New Haven: Yale University Press.

Ricoeur, P. (1974). The Conflict of Interpretations: Essays in Hermeneutics (ed. Don Ihde, trans. Willis Domingo et al). Evanston: Northwestern University Press.

Ricoeur, P. (1978). The Rule of Metaphor: Multi-Disciplinary Studies in the Creation of Meaning in Language (trans. Robert Czerny et al). London: Routledge and Kegan Paul.

Ricoeur, P. (1980). Essays on Biblical Interpretation. Philadelphia: Fortress Press.

Ricoeur, P. (1995). Figuring the Sacred. Religion, Narrative and Imagination. Minneapolis: Fortress Press.

Ricoeur, P. (2008). From Text To Action. Exeter: Continuum.

Rynes, S., Bartunek, J., Dutton, J., \& Margolis, J. (2012). Care and compassion through an organizational lens: opening up new possibilities. Academy of Management Review, 37(4), 503-523.

Scherer, A. G., \& Palazzo, G. (2007). Toward a Political Conception of Corporate Responsibility: Business and Society Seen from a Habermasian Perspective. The Academy of Management Review, 32(4), 1096-1120.

Schneider, A., \& Schmidpeter, R. (2012). Corporate Social Responsibility: verantwortungsvolle Unternehmensführung in Theorie und Praxis. Berlin: Springer Gabler.

Slawinski, N., \& Bansal, P. (2015). Short on Time: Intertemporal Tensions in Business Sustainability. Organization Science, 26(2), 531-549.

Tracey, P., Phillips, N., \& Lounsbury, M. (2014). Taking Religions Seriously in the Study of Organizations. In P. Tracey, N. Phillips, \& M. Lounsbury (Eds.), Religion and Organization Theory (pp. 3-21). Bingley: Emerald (= Research in the Sociology of Organizations 41).

Trowbridge, R. H. (2011). Waiting for Sophia: 30 Years of Conceptualizing Wisdom in Empirical Psychology. Research in Human Development, 8(2), 149-164.

Whittington, J. L., Pitts, T. M., Kageler, W. V., \& Goodwin, V. L. (2005). Legacy leadership: The leadership wisdom of the Apostle Paul. The Leadership Quarterly, 16(5), 749-770.

\section{Submit your manuscript to a SpringerOpen ${ }^{\circ}$ journal and benefit from:}

- Convenient online submission

- Rigorous peer review

- Immediate publication on acceptance

- Open access: articles freely available online

- High visibility within the field

- Retaining the copyright to your article 